\title{
COMPARATIVE ANALYSIS OF MASS-BALANCED MODELS FOR A TROPICAL RESERVOIR TO ASSESS THE IMPACT OF A MANAGEMENT PRACTICE
}

\author{
KhATUN, M. H. ${ }^{1}$ - BARMAN, P. P. ${ }^{1,2}$ - LUPA, S. T. ${ }^{3}$-ZAHANGIR, M. M. ${ }^{4}$ - ASHA, S. N. ${ }^{1}$ - LIU, Q. ${ }^{1 *}$ \\ ${ }^{1}$ College of Fisheries, Ocean University of China, Qingdao, 266003 Shandong, P.R. China \\ ${ }^{2}$ Department of Coastal and Marine Fisheries, Sylhet Agricultural University, Sylhet, \\ Bangladesh \\ ${ }^{3}$ Department of Fisheries Management, Bangladesh Agricultural University, Mymensingh 2202, \\ Bangladesh \\ ${ }^{4}$ Department of Fish Biology and Biotechnology, Chittagong Veterinary and Animal Sciences \\ University, Chittagong 4225, Bangladesh \\ *Corresponding author \\ e-mail:qunliu@ouc.edu.cn
}

(Received $17^{\text {th }}$ Nov 2019; accepted $30^{\text {th }}$ Jan 2020)

\begin{abstract}
Mass-balanced models were constructed for pre and post fishing ban period to compare the possible impacts of the introduction of the fishing closure management practice on the reservoir resources through estimating the trophic status and energy flow. The decreased biomass of high value fishes (Carps, Sheatfishes, Tilapia, Anabas testudineus and Knife fishes) despite the implementation of fishing closure pinpoints the excessive fishing pressure on these target species. However, the increased biomass of minnows and clupeids may pose a serious threat to reservoir stability and sustainability altering the trophic structure. Mixed trophic impact indicates that functional groups at the lower trophic level had positive effect on most of the groups. The ratio of primary production/respiration was 13.154 and 1.969 during pre-ban and post-ban season respectively. The relative overhead increased $(22.48 \%)$ while ascendancy was found to be lower $(-0.43 \%)$ during the post-ban period. The reservoir was more vulnerable to disruptions before the implementation of fishing ban. Some ecosystem attributes such as TPP/TB, TB/TST, TPP/TR, TPP - TR reveal that the Kaptai reservoir gained higher resilience, stability, maturity and complexity in food web after discontinuing the unlimited fishing access but it still requires attention to overcome the stresses associated with human activities.
\end{abstract}

Keywords: Kaptai reservoir, ascendancy, food web, sustainable management, overfishing

Abbreviations: B: Biomass, BFDC: Bangladesh Fisheries Development Corporation, CI: Connectance Index, DC: Diet composition, EE-Ecotrophic efficiency, EwE: Ecopath with Ecosim, EX: export, $F$ fishing mortality, FCI: Finn's Cycling Index, FMPL: Finn's mean path length, M: Natural mortality, MTI: Mixed trophic impact, OI: Omnivory Index, P/B: Production/Biomass, P/Q: Production/Consumption, P/R: Production/Respiration, Q/B: consumption/biomass, SOI-System Omnivory Index, TB/TR: Total biomass/Total respiration, TB/TST: Total biomass/Total system throughput, TE: Transfer efficiency, TL: Trophic level, TPP/TB: Total primary production/Total biomass, TPP-TR: Total primary production - Total respiration, TST: Total system throughput, Y: Yield, Z: Total mortality

\section{Introduction}

The determination of ecosystem structure, flow of energy through trophic interaction and its functional integrity has been widely recognized to ensure a sustainable habitat for living resources (Christensen and Pauly, 1995). Information about ecosystem structure and functions measuring the transferred biomass within ecological groups and 
trophic efficiency could help investigate the possible impacts of changes on different groups and ecosystem as well (Christian et al., 1996). The ecological attributes of an ecosystem delineated from fish population, components of the community, environmental status and flow of energy indicate the quality of an ecosystem. The Ecopath model incorporated different approaches of theoretical ecology (Odum, 1969; Ulanowicz, 1986) to analyze the energy flows between ecosystem components and to define the ecosystem maturity, resilience and stability. It predicts the health of an ecosystem, trophic functioning and its capacity to uphold the biological production. Furthermore, ecosystem properties help to investigate how fish population response to natural and human-made perturbations and thus support effective fisheries management. Moreau et al. (2001) stated that, the output of Ecopath model contributes in the management decision process where multi-species inhabit together.

The Kaptai reservoir is considered as one of the largest supports for freshwater capture fisheries in Bangladesh. It shows both lacustrine and riverine characteristics due to its construction damming a river and multiple other uses by surrounding community. However, due to the rapid economic development and natural perturbations since last few decades the reservoir has experienced ecological changes and severe stresses. Multi-disciplinary uses of reservoir, hydroelectric power generation, overfishing, and oil discharge from mechanized fishing and navigation boats have posed a serious threat to the reservoir fishery and ecology by degrading the water quality. In general, the multiple uses of reservoirs along with excessive fishing pressure, changes in diet make these systems as "unstable ecosystem". The impact is evident by the remarkable decline in the productivity of high-value fishes in this reservoir (Khatun et al., 2019). This was due to high accessibility to this reservoir resource.

Therefore, the detailed study is warranted to get information of the developmental status of this ecosystem facilitating the thoughtful understanding on the structural and functional principles of the whole system, which will be helpful to know the impact of human perturbations. Unfortunately, no attempt has been carried out yet to know the structure, function, existing trophic interactions and energy flow among different functional groups of the Kaptai reservoir unifying the available information. A mass-balance ecosystem model summarizes the changes in the species and helps to compare the direct and indirect effects of one species on others and the overall functioning of the system as well. The ecosystembased software Ecopath with Ecosim (EwE) allows the analysis of mass-balance trophic models of aquatic ecosystem (Christensen et al., 2005). Furthermore, it helps to compare between the models of two different periods of same ecosystem.

Since the 1980's, fishing has been banned for different period in the Kaptai reservoir depending on season, weather, production target etc. However, fishing closure from May $1^{\text {st }}$ to July $31^{\text {st }}$ has become a routine management practice from the year 2003 onwards in this reservoir. Considering this, we constructed two models of the Kaptai reservoir ecosystem for two different periods with different management approaches, the pre ban fishing, 2001 and post ban fishing, 2016. The study was conducted to assess the possible effect of fishing closure on whole ecosystem, to quantify the energy flows and biomass of different ecological groups, to compare the ecosystem structure, trophic interactions and trophic efficiencies of pre and post fishing closure. In doing so, this contribution will help to know the significance of seasonal fishing banning management on the ecological production, health and stability of the tropical reservoir system. Further remedial management measures also could be suggested identifying the existing bottlenecks and executing the wise use of this reservoir resource. 


\section{Materials and methods}

\section{Study site}

The Kaptai reservoir $\left(22^{\circ} 22^{\prime} \mathrm{N}\right.$ and $23^{\circ} 18^{\prime} \mathrm{N}$ latitude, and $92^{\circ} 00^{\prime} \mathrm{E}$ and $92^{\circ} 26^{\prime} \mathrm{E}$ longitude), the largest synthetic freshwater reservoir of South-East Asia and first manmade reservoir of Bangladesh was constructed primarily for the purpose of hydroelectric power generation on the River Karnafuli in 1961 (Fig. 1). It encompasses an area of $688 \mathrm{~km}^{2}$ with the average depth of $9 \mathrm{~m}$ and average annual temperature of $27{ }^{\circ} \mathrm{C}$. It receives nutrient-enriched waters from rivers, which helps to increase biological productivity and sustain high value fisheries. About 73 species of fishes belonging to 47 genera and 25 families, 2 species of freshwater prawn and 1 species of dolphin have been described in this reservoir (Ahmed, 1999). Among these, 31 species contribute commercially. Artisanal fishing approaches are typically used here to exploit fishery. Unfortunately, indiscriminate use of multispecies gears without concerning about the proper mesh size and mechanization of fishing vessels are putting the signs of excessive fishing effort on the aquatic resources. Surprisingly, since 1999, clupeids have been dominating the reservoir as it breeds profusely in reservoir. In the early post-impoundment period carps used to be the predominant reservoir species contributing $81.4 \%$ of the total catch (Ahmed et al., 2006) but it steadily decreased to only $0.96 \%$ in 2016 (DoF, 2016). On the other hand, clupeids are increasing at a rate of $8.7 \%$ annually (Ahmed et al., 2006) while it contributed $59 \%$ of the total catch in 2016 (DoF, 2016).

\section{Modelling approach}

The preliminary Ecopath software was based on the approaches developed by Polovina (1984) to analyze flows of energy between ecological groups of an aquatic ecosystem. Later on, subsequent modifications took place (Christensen and Pauly, 1993; Pauly et al., 2000; Christensen et al., 2002) following Ulanowicz (1986). Moreover, Odum's theory of ecosystem development was also incorporated in Ecopath model. In this study, mass-balanced Ecopath models were constructed using 14 ecological components for pre fishing ban (2001) and post fishing ban (2016) periods integrating the available information on food intake, population dynamics, catch and biomass of same or similar system. We used a user-friendly Ecopath with Ecosim suite version 6.5 (Christensen et al., 2008) in our study to construct Ecopath models to compare the changes between the continuous fishing and self-imposed fishing ban. The assumption of EwE is based on the two following equations e.g. 1) production $=$ Catch + Predation + Net migration + Biomass + Accumulation + Other mortality; and 2) Consumption = Production + Respiration + Unassimilated Food. This is expressed by the following equation (Eq. 1) proposed by Christensen et al. (2005):

$$
B i *\left(\frac{P}{B}\right) i * E E i=Y i+\sum(B j) *\left(\frac{Q}{B}\right) j * D C i j+E X i
$$

Here, $B i$ defines the biomass of prey group $i ; P / B i$ is the production/biomass ratio of group $i ; E E i$ represents the ecotrophic efficiency; $Y i$ is its yield (fishery catch); $B j$ defines the biomass of predator group $j, Q / B j$ is the food consumption per unit biomass of $j$; DCji is the fraction of $i$ in the diet of $j$ and $E X i$ is the export of $(i)$. 

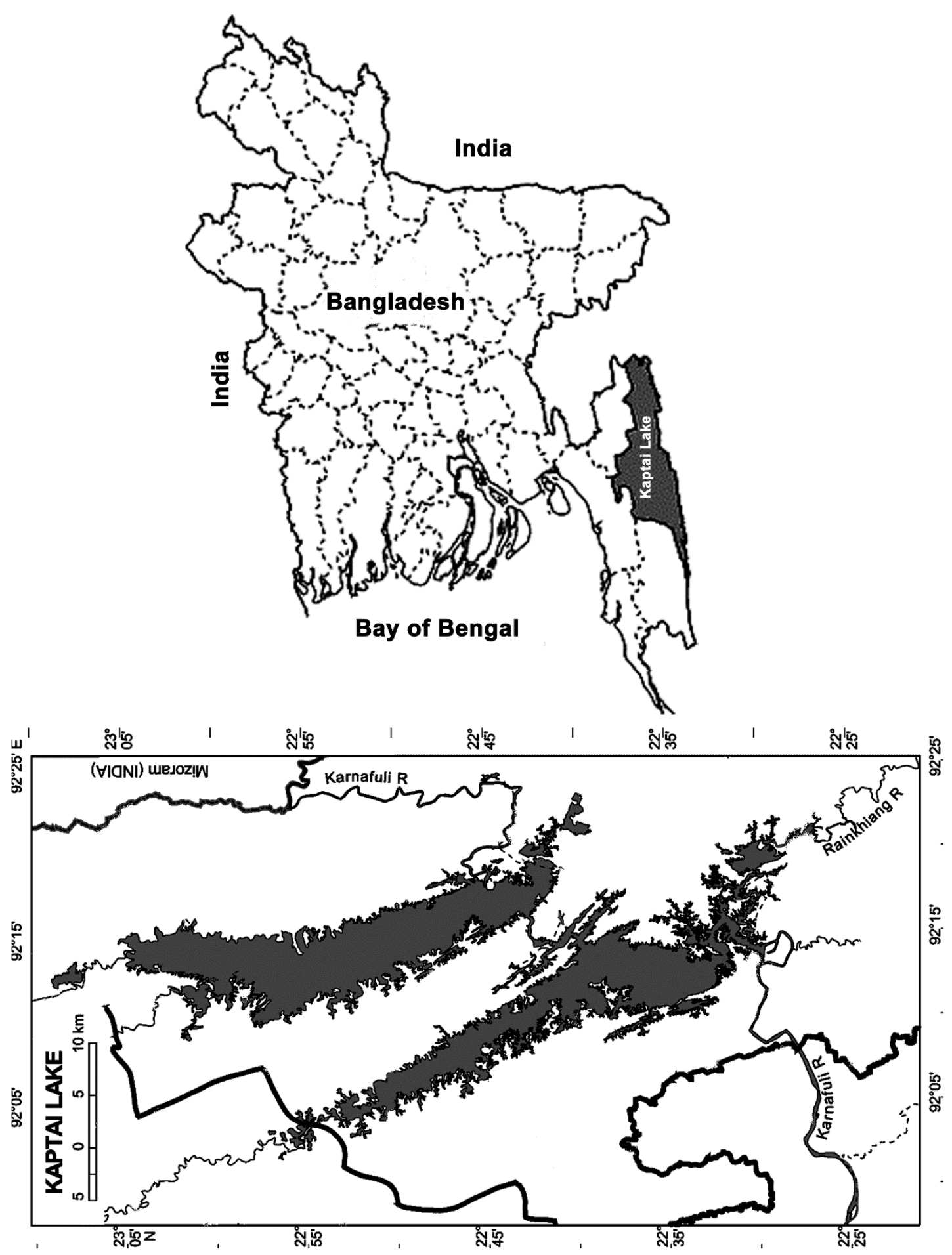

Figure 1. Geographical location of Kaptai reservoir

\section{Model parameterization}

The model input parameters include biomass $B\left(\mathrm{t} / \mathrm{km}^{2}\right)$, production/biomass $P / B\left(\mathrm{yr}^{-1}\right)$, consumption/biomass $Q / B\left(\mathrm{yr}^{-1}\right)$, Ecotrophic efficiency $(E E)$ and diet composition (must be entered as input). Inputting any three of the former parameters will estimate the fourth one. $E E$ is the proportion of the production that is consumed or predated. EE 
should be between 0 and 1 . Since there is no empirical relationship to calculate EE, Ecopath model calculates it as output (Christensen et al., 2000). However, in absence of any other parameter EE could be set as 0.95 for highly exploited groups (Christensen and Pauly, 1992). The biomass of both phases was determined from the annual landing information provided by Bangladesh Fisheries Development Corporation (BFDC). We used $B=Y / F$ (here $Y=$ annual average yield of a group, $F=$ fishing mortality) equation proposed by Gulland (1971) to calculate the biomass. In absence of landing data of any group, we used $E E$ as 0.95 (for minnows and prawns in 2001). The total fish biomass was found to be $5.256 \mathrm{t} / \mathrm{km}^{2}$ and $6.245 \mathrm{t} / \mathrm{km}^{2}$ during pre-ban and post-ban period respectively. $E E$ was also set as 0.95 to balance the model where the diet adjustment was ineffective. Notably, EE cannot be greater than 1 in a balanced model. The biomass of unexploited groups such as insects and larvae, zooplankton and phytoplankton for both phases was either estimated by the model or obtained from other models. The input and output values of both models are presented in Table 1.

The ratio of production over biomass $(P / B)$ is considered as equivalent to total mortality $Z$ (Pauly et al., 2000). Total mortality $Z$ (=Fishing mortality $F$ + natural mortality $M$ ) was estimated following Beverton and Holt (1993) while natural mortality $M$ was calculated using Pauly's empirical equation (Pauly, 1984). Consumption $(Q)$ is the food intake by a group over a specific period. Consumption/biomass $(Q / B)$ was calculated using the empirical equation developed by Palomares and Pauly (1998) along with the help of Fishbase database for every species of each group and the average value was taken as group $Q / B$ value. $\mathrm{P} / \mathrm{B}$ and $Q / B$ for some functional groups were obtained from other studied models (Table 1).

The diet matrix (Table A2 in the Appendix) of different groups was collected either from the available literatures (Khumar and Siddiqui, 1989; Mamun et al., 2004; Islam et al., 2006; Weliange and Amarasinghe, 2007; Azadi and Mamun, 2009; Sarkar and Deepak, 2009; Mondal and Kaviraj, 2010; Srivastava et al., 2012; Roy et al., 2013; Gupta, 2015; Sakhare and Jetithor, 2016) or from Fishbase (www.fishbase.org; Froese and Pauly, 2019). The model was balanced in a way so that for each group $E E$ does not exceed 1, $P / Q$ remains between 0.1 and 0.3 and $P / R$ ratio (production/respiration) ranges from 0 to 1. The estimated pedigree values were observed 0.56 and 0.533 for the year 2001 and 2016 respectively, which agrees with the statement of Christensen et al. (2002).

\section{Ecological groups}

Ecological groups were classified depending on population parameters, food and feeding habits, preference of habitat, physiology, taxonomy, body size and distribution. About 14 functional groups for each year including nine fish groups and one group of prawn were selected as per their abundance and economic importance. The selection of other groups were based on their preference in fish diet. Despite of the role as grazing ground for carps we excluded macrophytes for their minor presence in diet matrix (Panikkar et al., 2015). We used information from available literatures (see Table A1) and FishBase (www.fishbase.org; Froese and Pauly, 2019) to bridge the gaps.

\section{Carps}

Carps are the most popular reservoir fishes. The most dominant carps include Labeo rohita, Catla catla, Cirrhinus cirrhosis, Labeo calbasu, Labeo bata, Labeo gonius and Cyprinus carpio. Stocking of carps is a routine management practice in Kaptai 
reservoir, which is done to decrease the reduction of fish due to excessive fishing pressure. Despite of this stocking a clear declining trend has been noticed in carp production. These fishes feed on zooplankton, phytoplankton, detritus etc.

Table 1. Input features of the Ecopath models for pre-fishing ban (2001) and post-fishing ban period (2016) for Kaptai reservoir

\begin{tabular}{|c|c|c|c|c|c|c|c|c|}
\hline $\begin{array}{c}\text { Group } \\
\text { no. }\end{array}$ & Functional group & \begin{tabular}{|c|} 
Trophic \\
level $(T L)$
\end{tabular} & \begin{tabular}{|l} 
Biomass \\
(B) $\left(\mathbf{t} / \mathbf{k m}^{2}\right)$
\end{tabular} & $\begin{array}{c}P / B \\
\left(\mathrm{yr}^{-1}\right)\end{array}$ & $\begin{array}{c}Q / B \\
\left(\mathbf{y r}^{-1}\right)\end{array}$ & $\begin{array}{c}\text { Ecotrophic } \\
\text { efficiency }(E E)\end{array}$ & $P / Q$ & OI \\
\hline \multicolumn{9}{|c|}{ (a) Pre fishing ban } \\
\hline 1 & Carps & 2.143 & 0.396 & 3.038 & 18 & 0.824 & 0.169 & 0.137 \\
\hline 2 & Catfishes & 3.261 & 0.71 & 1.432 & 14.9 & 0.706 & 0.096 & 0.284 \\
\hline 3 & Sheatfishes & 3.186 & 0.161 & 5.59 & 18.4 & 0.264 & 0.304 & 0.506 \\
\hline 4 & Tilapia & 2.316 & 0.71 & 1.39 & 23.8 & 0.268 & 0.058 & 0.237 \\
\hline 5 & Anabas testudineus & 2.971 & 0.056 & 2.85 & 10.9 & 0.331 & 0.261 & 0.305 \\
\hline 6 & Knife fishes & 3.257 & 0.768 & 1.19 & 9.8 & 0.035 & 0.121 & 0.178 \\
\hline 7 & Snakehead & 3.251 & 0.178 & 3.13 & 11.4 & 0.95 & 0.275 & 0.297 \\
\hline 8 & Minnows & 2.137 & 0.797 & 5.4 & 57.56 & 0.95 & 0.094 & 0.125 \\
\hline 9 & Clupeids & 2.580 & 1.48 & 6.63 & 25.8 & 0.530 & 0.257 & 0.313 \\
\hline 10 & Prawns & 2.512 & 2.580 & 3.16 & 12.64 & 0.950 & 0.250 & 0.329 \\
\hline 11 & Insects/Larvae & 2.132 & 3.84 & 4 & 30 & 0.837 & 0.133 & 0.121 \\
\hline 12 & Zooplankton & 2.053 & 12.85 & 35 & 140 & 0.310 & 0.250 & 0.0526 \\
\hline 13 & Phytoplankton & 1.00 & 57 & 184 & - & 0.148 & - & - \\
\hline 14 & Detritus & 1.00 & 0.35 & - & - & 0.036 & - & 0.115 \\
\hline \multicolumn{9}{|c|}{ (b) Post fishing ban } \\
\hline 1 & Carps & 2.143 & 0.212 & 3.038 & 18.00 & 0.950 & 0.169 & 0.137 \\
\hline 2 & Catfishes & 3.266 & 1.375 & 0.900 & 5.250 & 0.982 & 0.171 & 0.296 \\
\hline 3 & Sheatfishes & 3.187 & 0.141 & 2.795 & 18.40 & 0.950 & 0.152 & 0.508 \\
\hline 4 & Tilapia & 2.316 & 0.394 & 1.390 & 23.80 & 0.753 & 0.058 & 0.237 \\
\hline 5 & Anabas testudineus & 2.971 & 0.037 & 3.790 & 10.90 & 0.757 & 0.348 & 0.305 \\
\hline 6 & Knife fishes & 3.257 & 0.384 & 1.190 & 9.800 & 0.282 & 0.121 & 0.178 \\
\hline 7 & Snakehead & 3.362 & 0.242 & 3.130 & 11.40 & 0.950 & 0.275 & 0.206 \\
\hline 8 & Minnows & 2.137 & 1.430 & 2.915 & 56.05 & 0.950 & 0.052 & 0.125 \\
\hline 9 & Clupeids & 2.580 & 2.03 & 7.570 & 46.30 & 0.744 & 0.163 & 0.313 \\
\hline 10 & Prawns & 2.512 & 3.234 & 3.160 & 12.64 & 0.950 & 0.250 & 0.329 \\
\hline 11 & Insects/Larvae & 2.132 & 4.125 & 4.000 & 30.00 & 0.950 & 0.133 & 0.121 \\
\hline 12 & Zooplankton & 2.053 & 12.85 & 35.00 & 140.0 & 0.373 & 0.250 & 0.053 \\
\hline 13 & Phytoplankton & 1.000 & 11.7 & 203.0 & - & 0.671 & - & - \\
\hline 14 & Detritus & 1.00 & 1.00 & - & - & 0.243 & - & - \\
\hline
\end{tabular}

$* P / Q$ defines production/consumption, $O I$ represents omnivory index

\section{Catfishes}

Mystus spp. formed this group. M. aor and M. seenghala are the dominant catfishes in this reservoir. Other catfish includes $M$. cavasius, M. vittatus and M. tengara. Catfishes are mainly caught by gill net, seine net and sometimes by hook and line. They 
are voracious eater and carnivorous by nature. Their food consists of carps, minnows, clupeids, insects and larvae, etc. Cannibalism is also a common feature among catfishes.

\section{Sheatfishes}

Wallago attu and Ompok pabda are grouped as sheatfishes. A decreasing trend during the study periods suggests excess fishing pressure on these fishes. Minnows, Prawns and Detritus were found as their main food item.

\section{Tilapia}

Both species of Tilapia, Oreochromis mossambicus and O. niloticus are dominant in this reservoir and play an important role in the total reservoir production. They are well known as voracious feeder and feed on mainly on phytoplankton and zooplankton. Tilapia can survive in much stress conditions.

\section{Anabas testudineus}

Anabas testudineus, locally known as koi is a popular freshwater perch in Bangladesh. The decrease production of this fish even after banning fishing reveals excessive fishing pressure on it. They feed on zooplankton, minnows, clupeids, insects and larvae, etc.

\section{Knife fishes}

The production record states that the productivity of Notopterus notopterus and $N$. chitala has decreased two times recently than the unlimited fishing access period. Knife fishes feed on small fishes, prawns, insects and larvae and so on.

\section{Snakehaed}

Channa marulius, $C$. striatus and $C$. punctatus constitute this group. These airbreathing fishes are mainly piscivorous and feed on small fishes especially minnows, clupeids and prawns. The production of these voracious feeders declined despite of the fishing ban implementation.

\section{Minnows}

Puntius sarana and Amblypharyngodon mola are the most abundant minnows of Kaptai reservoir. The closure of fishing management helped this fishery to increase tremendously. These fishes are caught on any small mesh size nets, hooks and dragnets. They feed on phytoplankton, zooplankton and minor portion of detritus.

\section{Clupeids}

Corica soborna and Gudusia chapra, commonly known as "weed fishes" contribute the major portion in the reservoir fishery as the breed profusely there. According to the production history, their production increased at higher rate after the introduction of the fishing closure. Interestingly, they compete for their diet with carps providing a forage base for catfish development. Zooplankton, phytoplankton, detritus and aquatic insects mainly form their diet. 


\section{Prawns}

The freshwater prawn Macrobrachium lamarrei is commonly available type of prawns in Kaptai reservoir. Since there is no information available for this species, we adopted the input data from Reyes (1993). Detritus forms their main diet besides insects and larvae, zooplankton and phytoplankton.

\section{Insect/larvae}

Aquatic insects and larvae play important role in the diet of carps, minnows and clupeids. This functional group consist of midges, mayflies, caddisflies, caddisworms, oligochaetes, insect larvae, bivalves and gastropods. We adopted the input value of this ecological group from Villanueva et al. (2006).

\section{Zooplankton}

The main constituting form of zooplankton refers to Copepods (Diaptomus, Cyclops and nauplii), cladocerans (Daphnia, Cheriodaphnia, Moina), and rotifers (Keratella, Filinia, Brachionus, Asplanhna). These are the main food item of major and minor carps, Tilapia and A. testudineus. Limited data encouraged us to adopt data from other models (Lauzanne, 1983; Moreau and Villanueva, 2002; Traore et al., 2008).

\section{Phytoplankton}

Chlorophyceae, Myxophyceae, Bacillariophyceae and Dinophyceae create the phytoplankton group. Among them Chlorophyceae (Spirogyra, Volvox, Coelastrum and so on), Myxophyceae notably Microcystis, Bacillariophyceae (Navicula, Gyrosigma, Fragilaria etc.) and Dinophyceae such as Ceratium and Peridinium are dominant here. Information of phytoplankton for pre-ban and post-ban phase were obtained from Traore et al. (2008) and Panikkar et al. (2015) respectively. Balancing the models was also the reason of this choice.

\section{Detritus}

We used the biomass of detritus as $0.35 \mathrm{t} / \mathrm{km}^{2}$ for the year of 2001 (Panikkar et al., 2015) and $1 \mathrm{t} / \mathrm{km}^{2}$ for the year of 2016 (Traore et al., 2008) from similar systems. The biomass of detritus adopted for both period was estimated using Pauly's equation of empirical relationship (Pauly et al., 1993).

\section{Model analysis}

Mixed trophic impact (MTI) routine developed by Ulanowicz and Puccia (1990) has been integrated in EwE to assess the relative impact biomass change of one group on another in an ecosystem trophically. Another routine incorporated with EwE that turns the complex food web into simpler one is defined as "Lindeman spine" (Lindeman, 1942). It aggregates the complex fractional trophic levels into discrete one and calculates the transferred energy flow and efficiency from one trophic level to the next. Ecopath can identify probable extinction prey group due to excessive predation by a large number of predator groups (Pauly et al., 2000). The impact of closure management practice on the basic pattern changes of reservoir system were determined comparing the trophic structure and transfer efficiency during both periods. This 
comparison will help the managers to get some ideas of the reservoir at ecosystem level and may drag their concern for further management steps.

A number of ecosystem attributes have been included in EwE following Odum (1971) to assess the ecosystem maturity. The comparison of net primary production/biomass, biomass/total system throughput, net primary production/total respiration and net primary production - total respiration - these four ecosystem indices were done to know the basic difference about the resilience of the reservoir in both phases. Another three attributes such as ascendancy, overhead and developmental capacity developed by Ulanowicz (1986) were compared to know the overall ecosystem health and stability in both periods.

\section{Results}

Some of the parameters of resulted mass-balanced Ecopath models explain the quantitative trends of pre and post ban-fishing implementation for Kaptai reservoir. Our study focus was to compare some parameters for same reservoir for pre-fishing closure period (2001) and post-fishing closure period (2016).

\section{Trophic relationship}

The basic inputs of the balanced models and the estimates are shown in Table 1. Close observation shows that the biomass of high value fishes such as Carps, Sheatfishes, Tilapia, Anabas testudineus and Knife fishes decreased between 2001 and 2016 despite of fishing closure. This might be due to the excessive fishing pressure on these target species, poor implementation of fishing acts, hazardous environment etc. The biomass of the top predator Snakehead and Catfishes along with some other low value fishes from trophic level II for instances minnows, clupeids and prawns increased after stopping the unlimited fishing access throughout the year. Study states that, in spite of fishing ban enforcement, $E E$ values of all commercially important fish groups were higher in 2016 compared to 2001 (Table 1). Important role of these groups in food web and huge predation pressure might be the reasons behind this. Lower $E E$ values of primary producer and detritus in 2001 compared to post fishing-ban explains them as underexploited during this period. $E E$ of phytoplankton in $2001(E E=0.148)$ indicates that most of the primary production died due to less predation pressure by plankton eater zooplankton. $E E$ value for detritus was higher in post fishing-ban phase $(E E=0.243)$ compared to pre fishing-ban phase $(E E=0.036)$ indicating that the lower accumulation of biomass than consumption. It reveals the better utilization of detritus by some groups (snakehead, clupeids, and minnows) with greater biomass in post fishing closure period.

\section{Trophic structure}

The trophic structure of the Kaptai reservoir has three trophic levels (Fig. 2). In both seasons' catfishes, sheatfishes, snakehead and knife fishes are found to be the top predators of the system (Table 1). The trophic levels could be either fractional (Christensen and Pauly, 1992) or integers (Lindeman, 1942). The resulted energy flows are shown in Figure 3 while the transfer efficiencies at each trophic level generated from the trophic aggregation routine are presented in Table 2. It shows that majorities of the biomasses and flows are concentrated in two lower trophic levels (I and II). Trophic 
level II mainly involved the flow from zooplankton (primary herbivore). TLIII involved the flows from clupeids, tilapia, Anabas testudineus and prawns while catfishes, sheatfishes, snakehead and knife fishes dominate the flow from trophic level IV. The mean transfer efficiency for 2001 and 2016 were $6.718 \%$ and $9.752 \%$ respectively (Table 2). The trophic aggregation routine shows the presence of six trophic levels in both seasons.

Table 2. Transferred efficiency at different trophic levels for pre fishing ban (2001) and post fishing ban period (2016) for Kaptai reservoir

\begin{tabular}{c|c|c|c|c|c|c|c}
\hline Phase/TL & II & III & IV & V & VI & $\begin{array}{c}\text { Mean transfer } \\
\text { efficiency (\%) }\end{array}$ & $\begin{array}{c}\text { Total flow proportion from } \\
\text { detritus }\end{array}$ \\
\hline Pre fishing ban & 3.743 & 11.17 & 7.255 & 6.232 & 7.458 & 6.718 & $46 \%$ \\
Post fishing ban & 5.378 & 12.55 & 13.74 & 13.83 & 16.18 & 9.752 & $32 \%$ \\
\hline
\end{tabular}

(a)

$\begin{array}{ll}0.850 & \square \text { No data } \\ 0.000 & \square \text { Individual }\end{array}$

4

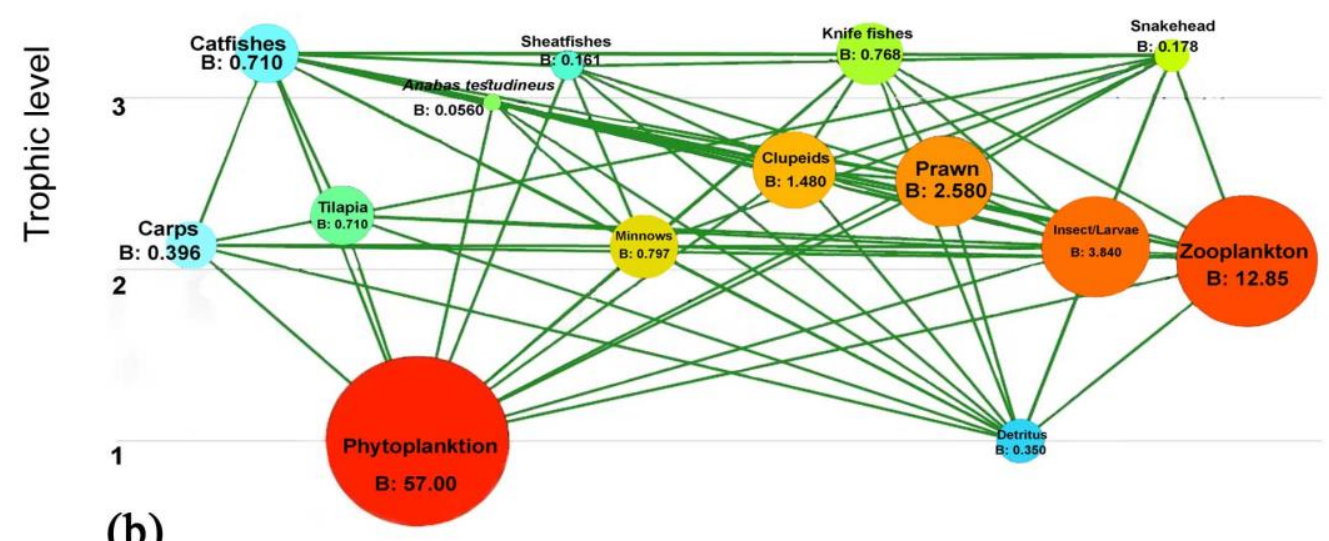

(b)

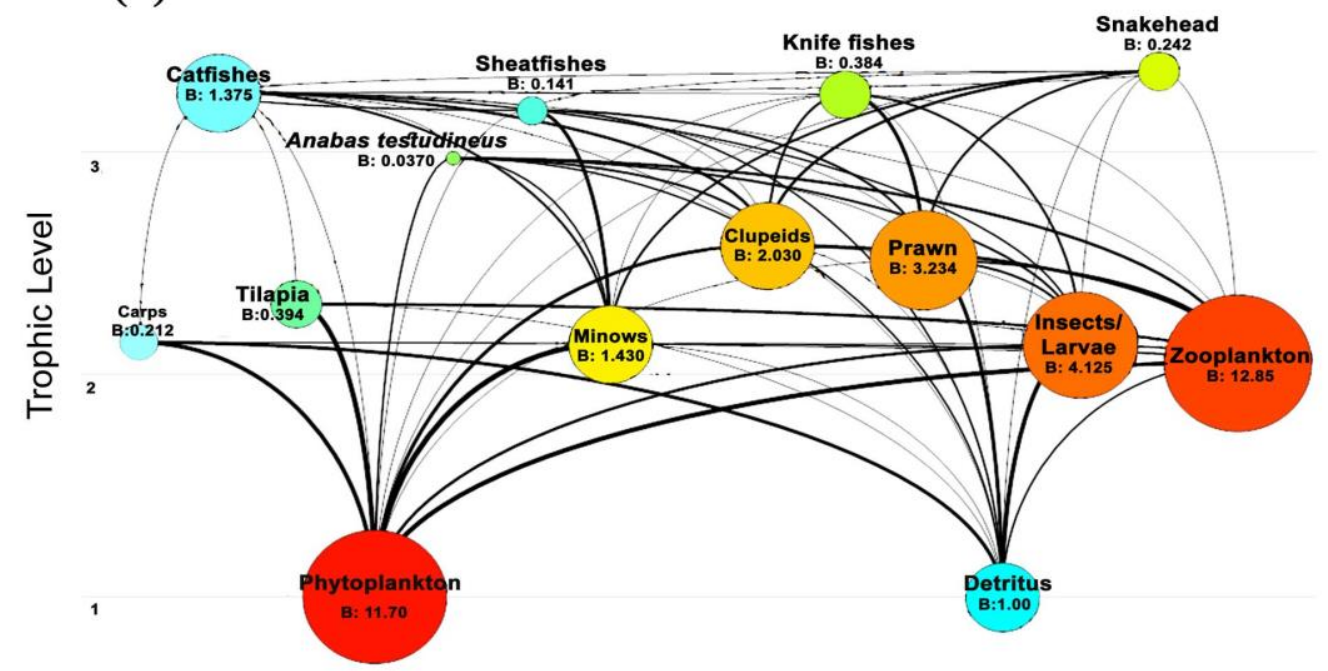

Figure 2. Food web structure of Kaptai reservoir with relative abundance, (a) Pre-ban phase (2001) and (b) post-ban phase (2016). B stands for biomass and 1, 2, 3, 4 represent the trophic levels 
(a)

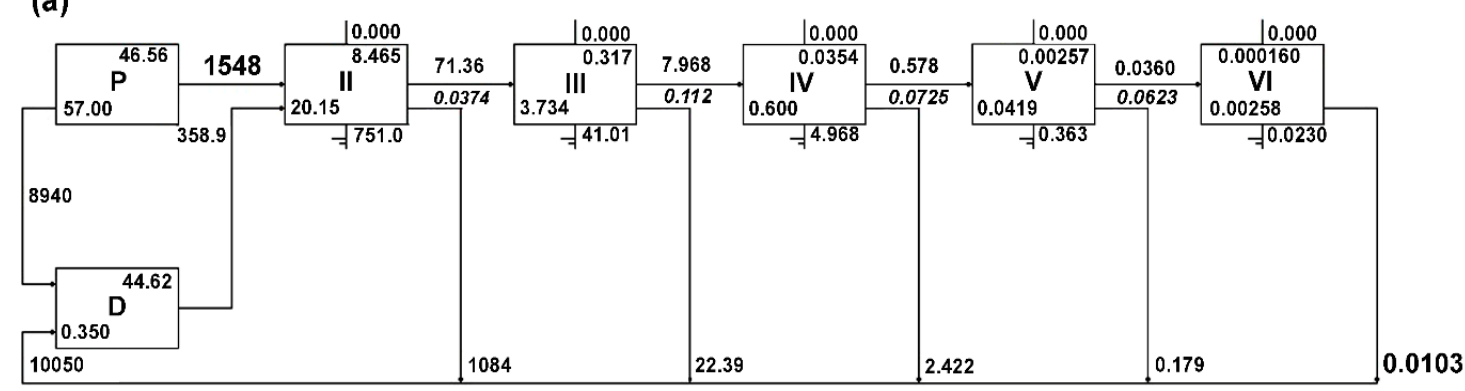

(b)
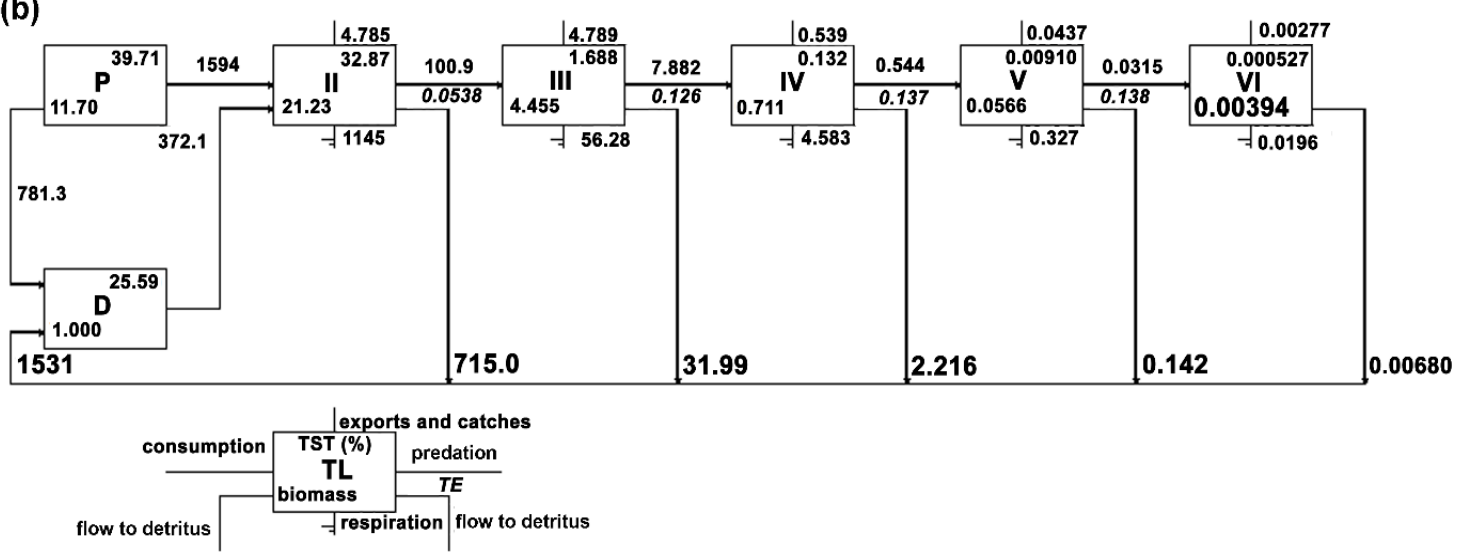

Figure 3. Trophic aggregation routine presenting transferred flows of Kaptai reservoir during (a) pre-ban phase, 2001 and (b) post-ban phase, 2016

\section{Mixed trophic impact}

The MTI routine on the Kaptai reservoir in two periods are illustrated in Fig. $4 a$ and $b$. It assesses the relative impact (direct or indirect) of increase of one group on others in the system. Prey and predator have positive and negative impact on each other respectively. Almost all groups had negative impacts on themselves suggesting competition for same resources. The insignificant decline exhibited by some groups was due to presence of competition within groups for food and habitat. Tilapia and Anabas testudineus had almost no effect on other groups. Minor increase in predator depicts the reduction of prey biomass. Functional groups at the lower trophic level such as phytoplankton and detritus shows positive effect on most of the groups. Phytoplankton shows positive impact on its primary consumers such as zooplankton, minnows, clupeids, tilapia and carps.

In contrast, zooplankton showed most negative effect on phytoplankton. The increase in phytoplankton biomass had positive effect on some groups at higher TL but minor negative impact on prawns in both periods. Snakehead had greater negative effect on maximum groups in pre fishing-ban phase than post fishing-ban period. Interestingly, it shows positive impact on catfishes in both seasons. An increased biomass of catfishes shows the decreasing of several groups biomass in both terms while the impact was greater in pre-ban time. Both catfish and snakehead had positive effect on prawns in pre fishing closure course but no effect after fishing ban period. However, the subsequent increase in catfishes led to the decline in the abundance of carps. 

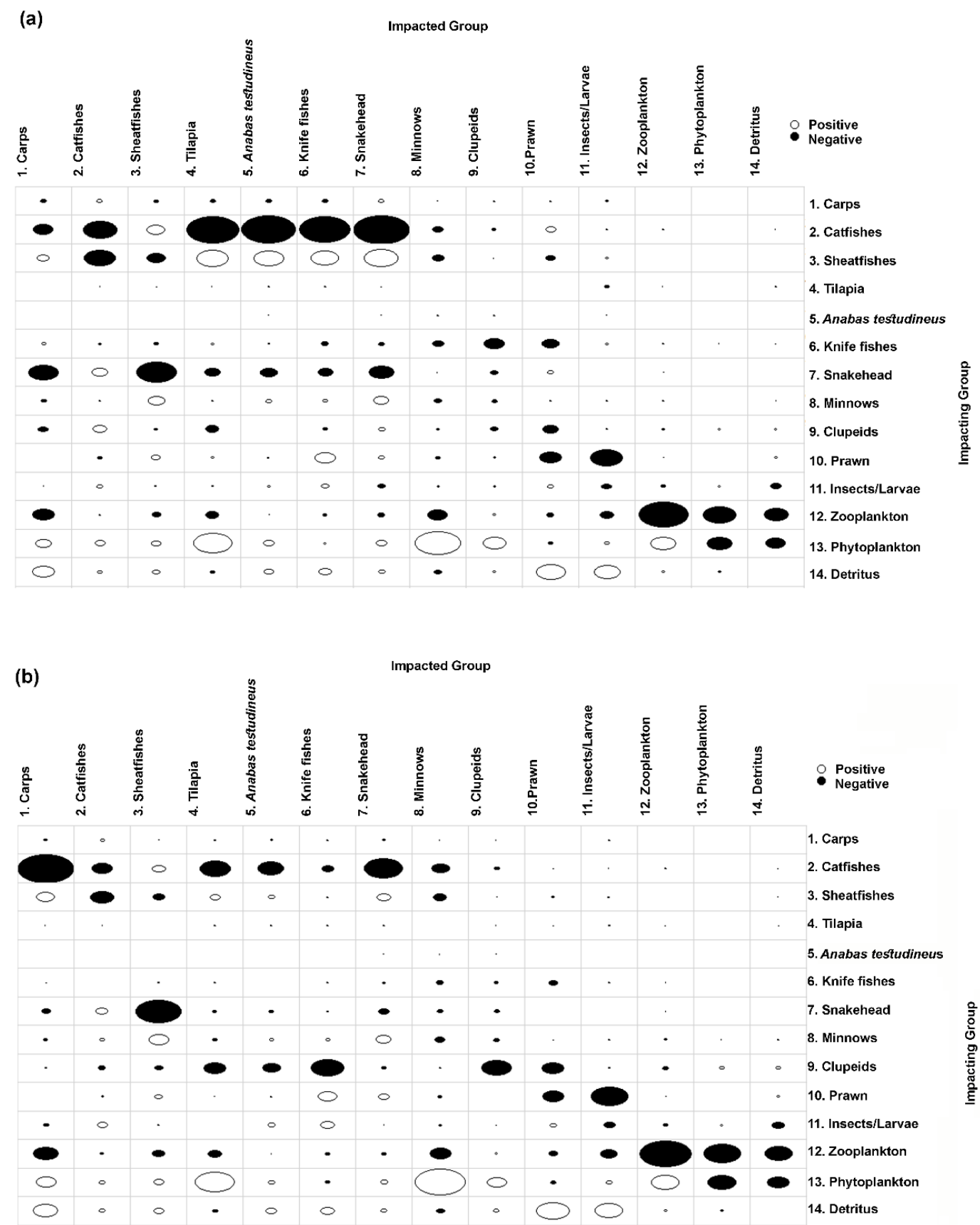

Figure 4. MTI of Kaptai reservoir, (a) pre fishing ban phase (2001) and (b) post fishing ban phase (2016). The circles (shaded black) indicate negative impacts and circles (without shade) indicate positive impacts. The size of the circles denotes relative response

\section{Summary statistics}

Ecopath computed some important indices of ecosystem maturity and stability supporting Odum's theory (Odum, 1969) and are shown in Table 3. A decrease of total system throughput, TST $(-73.144 \%)$ from pre fishing closure stage to post closure period is evident. An increase of total biomass/total system throughput (50\%) and a decrease of TST (-87.9\%), PP/B (-51.61\%) and PP/R (-11.185\%) were observed indicating the post ban period more stable and mature. About $84.76 \%$ detritus 
accumulation decreased from $10049.52 \mathrm{t} / \mathrm{km}^{2} / y$ ear during pre-fishing closure to $6073.396 \mathrm{t} / \mathrm{km}^{2} /$ year in post-ban period. The fish biomass of Kaptai reservoir was greater in post-ban phase $\left(6.245 \mathrm{t} / \mathrm{km}^{2}\right)$ than pre-ban phase $\left(5.256 \mathrm{t} / \mathrm{km}^{2}\right)$ which could be due to the presence of greater amount of small fishes in recent years.

Table 3. Summary attributes computed for pre-fishing ban (2001) and post-fishing ban period (2016) in Kaptai reservoir

\begin{tabular}{c|c|c|c|c}
\hline Indices & $\begin{array}{c}\text { Value pre- } \\
\text { ban }\end{array}$ & $\begin{array}{c}\text { Value post- } \\
\text { ban }\end{array}$ & Unit & $\begin{array}{c}\text { \% difference } \\
\text { Post ban - pre } \\
\text { ban / pre ban*\% }\end{array}$ \\
\hline Sum of all consumption & 2078.591 & 2167.709 & $\mathrm{t} / \mathrm{km}^{2} /$ year & \\
Sum of all exports & 9690.649 & 1168.645 & $\mathrm{t} / \mathrm{km}^{2} /$ year & \\
Sum of all respiratory flows & 797.351 & 1206.455 & $\mathrm{t} / \mathrm{km}^{2} /$ year & \\
Sum of all flows into detritus & 10049.52 & 1530.586 & $\mathrm{t} / \mathrm{km}^{2} /$ year & -84.76 \\
Total system throughput & 22616.109 & 6073.396 & $\mathrm{t} / \mathrm{km}^{2} /$ year & -73.144 \\
Sum of all production & 10981.11 & 2875.284 & $\mathrm{t} / \mathrm{km}^{2} /$ year & \\
Calculated total net primary production & 10488 & 2375.1 & $\mathrm{t} / \mathrm{km}^{2} /$ year & \\
Primary production required for catch & & 699.0 & $\mathrm{t} / \mathrm{km}^{2} /$ year & \\
Total primary production/total respiration & 13.154 & 1.969 & & -11.185 \\
Net system production & 9690.649 & 1168.645 & $\mathrm{t} / \mathrm{km}^{2} / \mathrm{year}$ & \\
Total primary production/total biomass & 128.647 & 62.250 & & -51.61 \\
Total biomass/total throughput & 0.004 & 0.006 & $/ \mathrm{year}$ & $50 \%$ \\
Net primary production-total respiration & 9690.649 & 1168.645 & & -87.94 \\
Total biomass (excluding detritus) & 81.526 & 38.154 & $\mathrm{t} / \mathrm{km}{ }^{2}$ & \\
Connectance index & 0.423 & 0.417 & & \\
System omnivory index & 0.196 & 0.198 & & \\
Ecopath pedigree index & 0.56 & 0.533 & & \\
Measure of fit, $\mathrm{t} *$ & 2.242 & 2.091 & & \\
Throughput cycled (including detritus) & 310.5 & 348.1 & $\mathrm{t} / \mathrm{km}^{2} / \mathrm{year}$ & \\
Ascendency & 52.61 & 30.13 & $\%$ & -0.43 \\
Overhead & 47.39 & 69.87 & $\%$ & 0.47 \\
Predatory cycling index (\% of throughput & 3.65 & 3.061 & & \\
without detritus) & & & & \\
Finn's cycling index & 1.373 & 5.732 & $\%$ of total & \\
Finn's mean path length & 2.156 & 2.557 & - & \\
\hline & & & & \\
\hline
\end{tabular}

Different flows such as total consumption, total exports, total flows into detritus and the total system throughput as well were bigger in 2001 than 2016 (Table 3). Greater values of ecosystem indices suggest that the food web of pre fishing ban season was better than the post- fishing ban period (Table 3). Ascendancy was found to be lower ($0.43 \%$ ) in post-ban season while overhead was lower in pre-ban (47.39\%) phase than post ban $(69.87 \%)$. Connectance index (CI) reflects the proportion of total probable connections in an ecosystem. On the other hand, system omnivory index (SOI) refers the diversification in diet of different groups. SOI is alternative to CI. The model for 2001 had 0.423 and 0.196 connectance index and SOI respectively while it was 0.417 and 0.198 respectively for the model of 2016. Both models had similar values for CI and SOI. 
Finn's cycling index (with detritus) increased at a considerable rate after stopping the unlimited fishing access. Higher Finn's cycling index (5.732) and mean path length (2.557) in post-ban time reveals the much more importance of detritus in the system.

The species with low biomass but structuring role in the ecosystem food web are defined as keystone species. They strongly influence the dynamics of the whole ecosystem and the abundance of other species maintaining their own low biomass (Libralato et al., 2006). The keystoneness of different functional groups of Kaptai reservoir before and after banning fishing is shown in Figure $5 a$ and $b$.
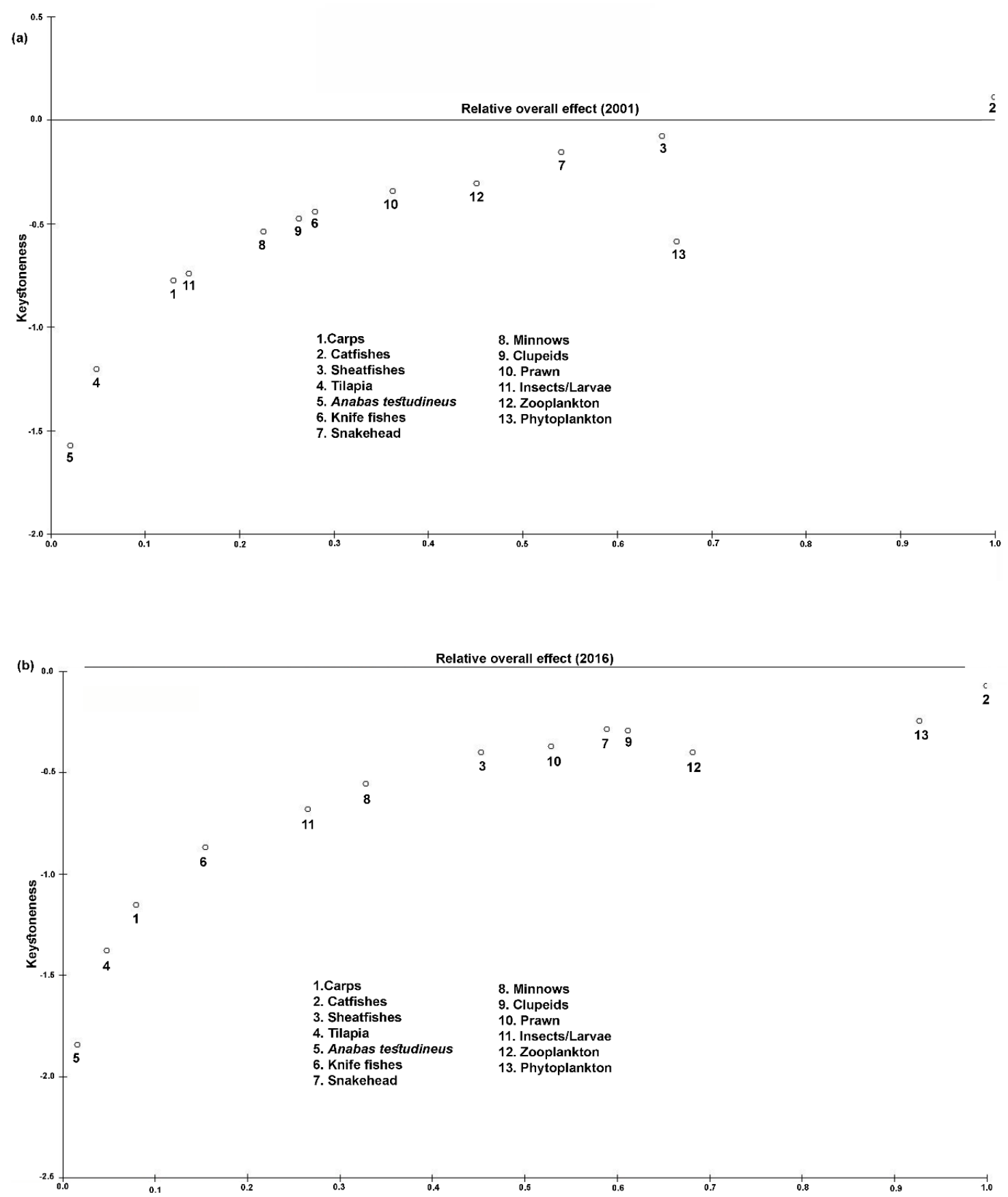

Figure 5. Keystoneness index for different ecological groups of Kaptai reservoir during a) preban (2001) and b) post-ban period (2016). Higher keystone index and higher relative overall effect denote the keystone species of this ecosystem 
The species are considered as keystone when the proposed keystoneness index value gets close to or greater than value "zero". Catfish, sheat fishes and snakehead were identified as keystone species in pre-ban period. In post-ban fishing time catfish stood as keystone species along with phytoplankton. In both terms, catfish had relatively higher effect and therefore it had an important role in the maintenance of the ecosystem structure.

\section{Discussion}

Sustainability of exploited resources and their effective management require ecosystem-based approach. We used Ecopath with Ecosim to balance the biomass and annual yield of the main interacting groups of pre stopping unlimited access for fishing (2001) and post fishing closure period (2016). Current work will visualize the existing reservoir ecosystem' complexity to the respective management bodies, which may help them to modify the present fishery regimes. The higher ecotrophic efficiency of some groups such as catfish, tilapia, sheatfishes, and Anabas testudineus in post-ban fishing period can be attributed either by increasing fishing predation or by predation pressure by other groups (Gamito and Erzini, 2005). The less abundant groups with higher EE (tilapia, sheatfishes, and Anabas testudineus) during post-fishing closure season indicates that they utilized the available biomass more efficiently. The flow to detritus of these groups were also lower compared to pre fishing ban period because of the higher competition of the consumers. This supports the finding for Lake Nakuru (Moreau et al., 2001). The increasing biomass with increasing EE (i.e. clupeids) might be due to the raise in predator biomass (e.g. catfish) in post-ban time. Low EE of phytoplankton (pre ban phase) granting the presence of Tilapia which mainly feed on phytoplankton might be due to grand biomass of phytoplankton or may have any other alternative food source (Fetahi and Mengistou, 2007). The exclusion of bacteria as a functional group might attributed to the lower EE of phytoplankton in 2001 (Fetahi and Mengistou, 2007). The decrease of some groups due to uncontrolled fishing effort and relatively higher predation rate may cause the ultimate increase of some other groups. For example, the biomass of minnows and clupeids increased as they had weaker completion for food with Carps or lower predation risk on them. This may lead alterations in trophic structure and could be a potential threat for reservoir stability and sustainability of the reservoir resources.

Theoretical ecology says, transfer efficiency decrease approaching toward the higher trophic levels (Odum, 1971) and this decreasing trend was observed in both phases in the Kaptai system. Comparatively low transfer efficiency was found in pre-ban phase $(6.718 \%)$. It could be due to the lower utilization of primary producer during this phase. However, Moreau et al. (2001), Tomaczak et al. (2005), and Panikkar and Khan (2008) also documented a low value of transfer efficiency in their studies due to the same reason. The mean transfer efficiency this system after banning period $(9.752 \%)$ was within the average range (8-15\%) (Christensen and Pauly, 1993; Wolff, 1994). The post-ban transfer efficiency was higher than the observation of same phase from Wyra reservoir (7\%) and lower than other studies (Bradford-Grieve et al., 1994; Mohamed et al., 2005). In addition, TE of TLV was lower than TLVI, which suggests that a smaller scale of production consumed within this trophic level. Furthermore, the greater TE at every TL after post-ban period indicates better energy flows within the system network. It suggests that, during post fishing ban period most of the groups were utilized at 
higher level by either fishing predation or predation by other groups. In addition, detritus was found to be about $46 \%$ of total system throughput in pre ban phase and $32 \%$ in post-ban stage indicating its important role in the ecosystem. It implies the reservoir system as phytoplankton based while importance of detritus as food was also evident. The contribution of detritus in Kaptai reservoir supports the range of other tropical system (Christensen and Pauly, 1993).

Mixed trophic impact is known as an ordinary form of sensitivity analysis (Majkowski, 1982). It helps to predict the direct and indirect impact of one group on others in near future. Group competition for same resources was obvious in both phases as all groups had negative impact on themselves except detritus (Christensen et al., 2000). Detritus, as it is not a living group, had no effect on itself in Kaptai system like other studies (Christensen and Pauly, 1993; Moreau et al., 2001; Fetahi, 2005; Fetahi and Mengistou, 2007; Panikkar and Khan, 2008). The positive effect of detritus on most groups would have beneficial role for detrivorous fish groups, especially for prawns. This observation is supported by Gamito and Erzini (2005) and Panikkar and Khan (2008). Phytoplankton had positive impact on most groups but interestingly it had negative impact on itself, which might be due to the competition for nutrients (Moreau et al., 1997). No impact of Tilapia and Anabas testudineus might be attributed due to the presence of their very low biomass in the system or may be their main food item was not entered to the diet matrix due to limited information (Neira et al., 2004). Bangladesh Fisheries Development Corporation (BFDC) liberates $30 \mathrm{mt}$ of carp fingerlings every year in the Kaptai reservoir. Nevertheless, a noticeable decline of carps due to the increase in catfish biomass was observed during this study. Catfishes exert predation pressure on stocked carps (see Table A2). Future works are suggested to investigate why the carp production does not increase in spite of huge fingerling liberation. Does the predation pressure by the catfishes solely influence their tremendous reduction or is there any other hidden reasons related to environmental changes?

Ecosystem undergoes through many developmental phases and acquires maturity by the orderly succession of community development (Odum, 1969). Ecopath computes some important ecosystem indices related to ecosystem maturity and stability (Christensen, 1995). The present comparative mass-balance models of before and after fishing closure shows the health development of the tropical Kaptai reservoir due to this management practice. TST in pre-ban phase was greater than post-ban phase as younger ecosystem has higher TST. The decrease of the flows throughout the system during post-ban period along with ascendancy supports the finding of Ulanowicz (1986), and Ulanowicz and Norden (1990). The ratio of total biomass on total system throughput (TB/TST) should increase over time and maturity. In mature system, it stores energy in system' components and conserve it (Ulanowicz, 1986). Again, total primary production/total biomass (TPP/TB) tends to be lower from developmental phase toward mature state due to high biomass or low production rate (Christensen, 1995). The ratio of total primary production/total respiration, TPP/TR tends to be "1" for mature system. Higher TPP/TR (13.154) in pre-ban phase compared to post-ban (1.969) interprets the later phase as more mature. It is obvious that the reservoir had enough strength to fight against human perturbations such as overfishing, pollution, water diversion etc. for acquiring this sort of maturity. TPP/TR values of both phases for Kaptai reservoir was higher than Wyra reservoir (Panikkar and Khan, 2008), Bakreswar reservoir (Banarjee et al., 2016). On the other hand, Ravishankar sagar reservoir (10.36) has greater TPP/TR than post-ban phase but lower compared to pre-ban phase of Kaptai reservoir 
(Panikkar et al., 2015). Christensen (1995) did study to rank the ecosystem maturity indicators and concluded that disturbances reduce maturity. The present paper also examines some of the vital ecosystem attributes such as TPP/TB, TB/TST, TPP/TR, TPP - TR and reveals that the Kaptai reservoir got more resilience after stopping the unlimited fishing access throughout the year than pre-ban phase. Therefore, the post-ban phase shows more maturity and stability as well compared to pre-ban phase.

Ascendancy and overhead are related to ecosystem stability, maturity, eutrophication and human perturbations (Aoki 1995; Christensen 1995; Ulanowicz, 1997; Neilsen and Ulanowicz, 2000). Overhead represents the presence of strength in an ecosystem to overcome any disturbances. The impact of the introduction of fishing closure is evident as the relative overhead increased $(22.48 \%)$ during the post-ban period. It also signifies more resilient trophic network in post-ban than pre-ban period supporting the findings of Althauser (2003). Nevertheless, about $10 \%$ changes in relative overhead was observed in marine upwelling system during pre and post stressed period (Heymans et al., 2004). The ascendancy and overhead values are comparable with the findings of Panikkar and Khan (2008) and Panikkar et al. (2015).

Connectance index (CI) and system omnivory index (SOI) denote the existing complexity in the food web structure and the diversity in diet matrix. These also describe the level of maturity of an ecosystem. CI and SOI values tend to be higher in mature ecosystem. The values of CI and SOI were found as $(0.423,0.196)$ in pre-ban phase and $(0.417,0.198)$ in post-ban phase respectively. The similar CI indicates the similar diet in both terms. CI and SOI of the Kaptai reservoir for both periods were comparatively greater than the Bakreswar reservoir (Banerjee et al., 2016), Ravishankar sagar reservoir (Panikkar et al., 2015) while it was similar to lake Ayame (Traore et al., 2008). Moreover, higher CI indicates the importance of detritus as alternative diet in the system, diversity in diet of some groups and some sort of maturity as well.

Finn's cycling index (FCI) has correlation with system maturity, stability and resilience. A higher FCI value represents more mature and stable ecosystem (Odum, 1969). Greater FCI in post-ban (5.732) phase than pre-ban (1.373) supports more maturity and resilience during post-ban phase. FCI values for the kaptai reservoir was lower than Bakreswar reservoir (Banarjee et al., 2016) while greater than Ravishankar sagar reservoir (Panikkar et al., 2015). Ecopath computed predatory cycling index (PCI) excluding detritus cycles. PCI was a bit higher in pre-ban period (3.65) than post-ban (3.06). FCI and PCI values also support the statement of being more mature, complex and detritus dependent ecosystem. Higher Finn's mean path length (FMPL) in post fishing closure period (2.557) compared to pre fishing closure era (2.156) also suggest post-ban period with more maturity and complexity. However, high FCI value indicates an ecosystem as mature one but a very high value describes the ecosystem at vulnerable condition (Christensen and Pauly, 1993). In that sense, the Kaptai reservoir seems to be a bit sensitive to disruptions.

A similar study was done to assess the impact of fishing ban management practice for a tropical Wyra reservoir, India (Panikkar and Khan, 2008). They found $(-82.7 \%)$ decrease of total flows during post-ban period while it decreased $(-73.144 \%)$ in Kaptai reservoir. Lower ascendency $(-0.14 \%)$ and higher overhead $(0.05 \%)$ after the introduction of fishing closure supports our finding for Kaptai reservoir. TPP/TR for both reservoirs decreased after the implementation of management approach but it was closer to 1 for Wyra reservoir (1.053) compared to Kaptai reservoir (1.969) indicating Wyra more mature. In brief, the comparative mass-balanced models for pre-ban (2001) 
and post-ban period (2016) support the improvement of "health" for Kaptai reservoir due to management interventions during this period. The similar observed improvement for Wyra reservoir encourages implementing this environmental management measure for the stability of the reservoir and its resources.

Moreover, overfishing, both in marine and freshwater sector is a matter of concern nowadays to meet the increasing food security throughout the world. It does not only influence the aquatic resources but also the ecosystem. These are the driving forces to do detailed study of the aquatic ecosystems to ensure efficient management for the sustainability of the aquatic resources and greater the stability of the reservoir ecosystem. Uncontrolled fishing pressure impact the trophic structure of an ecosystem significantly. It also accelerates the rapid reproduction and reduce the size of fishes (Travers et al., 2010). Thus, the decrease of top predators from higher trophic levels and the increase of smaller size fishes was termed as "fishing down the food web". Overfishing accelerate the fish species to suffer from the reduction of genetic diversity within and among population for long time before extinction (Musick et al., 2000). Selective fishing intensifies the alteration of genetic diversity, heritable difference in yield and life history traits of any particular fish species (Reviewed by Kenchington, 2003). Calculating the effects of overfishing on the molecular genetic level and in understanding life history traits will be helpful to get prior idea about stock status and level of extinction of any particular species. Further studies are suggested to know the possible effects of overfishing on ecosystem and molecular level.

\section{Conclusion}

Ecosystem modelling are now widely used for stock assessment and for the development of fisheries management policies for tropical fisheries. This study explains how fishing closure management helped the reservoir to get more maturity, stability, resilience and more complexity in food web than previous period. Moreover, TPP/TR near to unity predicts the reservoir as a healthy ecosystem but still it seeks attention to overcome the stress due to exercising overfishing. Our study also reveals that the Kaptai reservoir was more vulnerable to disruptions before the introduction of fishing ban management practice. In spite of its remarkable contribution to the capture fisheries of Bangladesh due to natural and human perturbations especially for the high catching activities, the reservoir resources have collapsed. Although, the fishing closure management step along with other practices led this system to achieve more maturity than before but still the reservoir fishery has been experiencing excessive fishing effort. Therefore, we can conclude that further necessary ecosystem-based management actions will help to be a sustainable aquatic resource in Bangladesh fighting against any natural or anthropogenic perturbations. Notably, the most abundant but low economic fish in the reservoir such as Corica soborn, Gudusia chapra could be used as processed food or as fishmeal. This paper provides a framework of better understanding of the trophodynamics of the Kaptai reservoir and the effects of taking environmental-based fisheries management. However, the scarcity of relevant data and uncertainties in input parameters especially for lower trophic level could be some feasible limitations of this study. Despite of these uncertainties we regard that the constructed models provide reasonable presentation of the Kaptai ecosystem structure and dynamics. Therefore, future works for instances collecting data with intensive care for further study related to ecosystem dynamics, study of effects of climate changes and pollutants on reservoir 
resources, detailed study of the present modelling using Ecosim are recommended to explore new fishery policies for the reservoir sustainability.

Acknowledgements. All authors show immense gratitude to the Chinese Scholarship Council and Ocean University of China for their support in this journey.

\section{REFERENCES}

[1] Ahmed, K. K. (1999): Options for the management of major carp fishery in Kaptai reservoir, Bangladesh. - PhD Dissertation, School of Environment, Resources and Development, Asian Institute of Technology, Bangkok.

[2] Ahmed, K. K., Rahman, S., Ahammed, S. U. (2006): Managing fisheries resources in Kaptai reservoir, Bangladesh. - Outlook on Agriculture 35(4): 281-289.

[3] Ahmed, K. K. U., Amin, S. M. N., Haldar, G. C., Dewan, S. (2003): Population dynamics and stock assessment of Oreochromis niloticus (Linnaeus) in the Kaptai Reservoir, Bangladesh. - Indian Journal of Fisheries 50(1): 47-52.

[4] Ahmed, K. K. U., Amin, S. M. N., Haldar, G. C., Dewan, S., Hossain, M. M. (2005): Population dynamics and stock assessment of Labeo rohita (Hamilton) in the Kaptai Reservoir, Bangladesh. - Asian Journal of Fisheries Science 18: 1-14.

[5] Althauser, L. (2003): An Ecopath/Ecosim analysis of an estuarine food web: seasonal energy flow and response to river-flow related perturbations. - Thesis Submitted to the Graduate Faculty of the Louisiana State University and Agricultural and Mechanical College, The Development of Oceanography and Coastal Sciences.

[6] Aoki, I. (1995): Flow-indices characterizing eutrophication in lake-ecosystems. Ecological Modelling 126: 131-137.

[7] Azadi, M. A., Mamun, A. (2009): Population dynamics of the cyprinid fish, Amblypharyngodon mola (Hamilton) from the Kaptai lake, Bangladesh. - Chittagong University Journal of Biological Science 2009: 141-151.

[8] Azadi, M. A., Mustafa, M. G., Naser, A. (1996): Studies on some aspects of population dynamics of Labeo bata (Hamilton) from Kaptai Reservoir, Bangladesh. - Chittagong University Studies, Part II: Science 20: 13-18.

[9] Banerjee, A., Banerjee, M., Mukharjee, J., Rakhit, N., Ray, S. (2016): Trophic relationships and ecosystem functioning of Bakreswar Reservoir, India. - Ecological Informatics 36: 50-60.

[10] Beverton, R. J. H., Holt, S. J. (1993): On the Dynamics of Exploited Fish Populations. - Chapman and Hall, London (facsimile, reprinted).

[11] Bradford-Grieve, L., Bull, M., Murdoch, R., Nodder, S. (1994): Summary of fisheries knowledge of the Tasman and Golden Bay Marine environment relevant to fisheries enhancement. - Report Prepared for Southern Scallops Fishery Advisory Committee MAF (Central) Tasman District Council.

[12] Christensen, V. (1995): Ecosystem maturity - towards quantification. - Ecological Modelling 77: 3-32.

[13] Christensen, V., Pauly, D. (1992): ECOPATH II-a software for balancing steady-state ecosystem models and calculating network characteristics. - Ecological Modelling 61(3-4): 169-185.

[14] Christensen, V., Pauly, D. (1993): Trophic Models of Aquatic Ecosystems. - World Fish, ICLARM Conference Proceedings 26, Manila.

[15] Christensen, V., Pauly, D. (1995): Fish production, catches and the carrying capacity of the world oceans. - Naga, ICLARM Q 18(3): 34-40.

[16] Christensen, V., Walters, C. J., Pauly, D. (2000): Ecopath with Ecosim: A User's Guide. - University of British Columbia. Fisheries Centre, Vancouver. 
[17] Christensen, V., Walters, C. J., Pauly, D. (2002): Ecopath with Ecosim Version 5, Help System $\odot$. - University of British Columbia. Fisheries Centre, Vancouver, BC, Canada.

[18] Christensen, V., Walter, C. J., Pauly, D. (2005): Ecopath with Ecosim: A User's Guide. - Fisheries Centre, University of British Columbia, Vancouver.

[19] Christensen, V., Walters, C. J., Pauly, D., Forrest, R. (2008): Ecopath with Ecosim Version 6 User Guide. - Lenfest Ocean Futures Project.

[20] Christian, R. R., Froese, E., Comin, F., Viaroli, P., Naldi, M., Ferrari, I. (1996): Nitrogen cycling networks of coastal waters: influence of trophic status and primary producer form. - Ecological Modelling 87(1-3): 111-129.

[21] DoF (2016): Yearbook of Fisheries Statistics of Bangladesh, 2016-2017. - Director General Department of Fisheries, Bangladesh, Dhaka.

[22] Fetahi, T. (2005): Trophic analysis of Lake Awassa using mass-balance Ecopath model. - A Thesis Presented to the School of Graduate Studies, Addis Ababa University, Department of Biology.

[23] Fetahi, T., Mengistou, S. (2007): Trophic analysis of Lake Awassa (Ethiopia) using mass-balance Ecopath model. - Ecological Modelling 201(3-4): 398-408.

[24] Froese, R., Pauly, D. (2019): FishBase. - World Wide Web Electronic Publication. www.fishbase.org.

[25] Gamito, S., Erzini, K. (2005): Trophic food web and ecosystem attributes of a water reservoir of the Ria Formosa (south Portugal). - Ecological Modelling 181(4): 509-520.

[26] Gulland, J. A. (1971): The Fish Resources of the Oceans West by Fleet. - Fishing News (Book) Ltd for FAO, Rome.

[27] Gupta, B. K., Sarkar, U. K., Bharadwaj, S. K. (2015): Analysis of morphometric characters and population dynamics of Ompok pabda (Hamilton, 1822) from Gomti River in Northern India. - Journal of Biological Science and Medicine 1(1): 49-58.

[28] Gupta, S. (2015): Review on Sperata seenghala (Sykes, 1839), a freshwater catfish of Indian subcontinent. - Journal of Aquatic Research Development 6: 290.

[29] Haroon, A. Y., Razzaque, A., Dewan, S., Amin, S. N., Rahman, S. L. (2001): Population Dynamics and Stock Assessment of Labeo rohita (Ham.), L. calbasu (Ham.) and L. gonius (Ham.) From the Mymensingh Basin. - Journal of Biological Science 1: 671-675.

[30] Heymans, J. J., Shanon, L. J., Jarre, A. (2004): Changes in the Northern Benguela Ecosystem over three decades: 1970s, 1980s, and 1990s. - Ecological Modelling 172: 175-195.

[31] Islam, M. S., Rahman, M. M., Halder, G. C., Tanaka, M. (2006): Fish assemblage of a traditional fishery and the seasonal variations in diet of its most abundant species Wallago attu (Siluriformes: Siluridae) from a tropical floodplain. - Aquatic Ecology 40(2): 263-272.

[32] Kenchington, E. L. (2003): The Effects of Fishing on Species and Genetic Diversity. In: Sinclari, M. et al. (eds.) Responsible Fisheries in the Marine Ecosystem. Chap. 14. CAB International, Wallingford.

[33] Khatun, M., Lupa, S., Rahman, M., Barman, P., Liu, Q. (2019): Evaluation of Labeo calbasu fishery status using surplus production models in Kaptai reservoir, Bangladesh. - Applied Ecology and Environmental Research 17(2): 2519-2532.

[34] Khumar, F., Siddiqui, M. S. (1989): Food and feeding habits of the carp Labeo calbasu Ham. in north Indian waters. - Acta Ichthylogica Et Piscatoria 1(19).

[35] Kumari, S., Sarkar, U. K., Mandhir, S. K., Lianthuamluaia, L., Panda, D., Chakraborty, S. K., Karnatak, G., Kumar, V., Puthiyottil, M. (2018): Studies on the growth and mortality of Indian River shad, Gudusia chapra (Hamilton, 1822) from Panchet reservoir, India. - Environmental Science and Pollutant Research 25: 33768-33772.

[36] Lauzanne, L. (1983): Trophic Relations of Fishes in Lake Chad. - In: Carmouze, J. P., Durand, J. R., Leveque, C. (eds.) Lake Chad: Ecology and Productivity of a Shallow Tropical Ecosystem. Junk Publ., The Hague, pp. 489-518. 
[37] Libralato, S., Christensen, V., Pauly, D. (2006): A method for identifying keystone species in food web models. - Ecological Modelling 195: 153-171.

[38] Lindeman, R. L. (1942): The trophic-dynamic aspect of ecology. - Ecology 23: 399417.

[39] Majkowski, J. (1982): Usefulness and Applicability of Sensitivity Analysis in a MultiSpecies Approach to Fisheries Management. - In: Pauly, D., Murphy, G. I. (eds.) Theory and Management of Tropical Fisheries. ICLRM Conference Proceedings 9, pp.149-165.

[40] Mamun, A., Tareq, K. M. A., Azadi, M. A. (2004): Food and feeding habits of Amblypharyngodon mola (Hamilton) from Kaptai reservoir, Bangladesh. - Pakistani Journal of Biological Science 7(4): 584-588.

[41] Mohamed, K. S., Zacharia., Muthiah, C., Abdurahiman, K. P., Nayak, T. H. (2005): A trophic model of the Arabian Sea Ecosystem off Karnataka and Simulation of Fishery Yields for its Multigear Marine Fisheries. - CMFRI Special Publication, Kochi, pp. 155 .

[42] Mondal, D. K., Kaviraj, A. (2010): Feeding and reproductive biology of Indian shad Gudusia chapra in two floodplain lakes of India. - Electronic Journal of Biology 6(4): 98-102.

[43] Moreau, J., Villanueva, M. C. (2002): Exploratory Analysis of Possible Management Strategies in Lake Victoria Fisheries (Kenyan Sector) Using the Recent Ecosim Software. - In: Pitcher, T., Cochrane, K. (eds.) On the Use of Ecosystem Models to Investigate Multi-Species Management Strategies for Capture Fisheries. Fisheries Center Research Report 10, pp.150-154. www.fisheries.ubc.ca.

[44] Moreau, J. C., Gertrud, G., Ian, H., Kit, K., Nils, K., Martina, M., Cecil, M., Brian, M. (1997): Biomass Flows in Lake Kariba, towards an Ecosystem's Approach. - In: Moreau, J. (ed.) Advances in the Ecology of Lake Kariba. University of Zimbabwe Publication, pp. 219-230.

[45] Moreau, J., Mavuti, K., Daufresne, T. (2001): A synoptic Ecopath model of biomass flows during two different static ecological situations in Lake Nakuru (Kenya). Hydrobiologia 458(1-3): 63-74.

[46] Musick, J. A., Harbin, M. M., Berkeley, S. A., Burgess, G. H., Eklund, A. M., Findley. L., Gilmore, R. G., Golden, J. T., Ha, D. S., Huntsman, G. R., McGovern, J. C., Sedberry, G. R., Parker, S. J., Poss, S. G., Sala, E., Schmidt, T. W., Weeks, H., Wright, S. G. (2000): Marine, estuarine and diadromous fish stocks at risk of extinction in North America (exclusive of Pacific salmonids). - Fisheries 25: 6-29.

[47] Mustafa, M. G., De Graaf, G. (2008): Population parameters of important species in inland fisheries of Bangladesh. - Asian Journal of Fisheries Science 21(2): 147-158.

[48] Mustafa, M. G., Singha, S., Islam, M. R., Mallick, N. (2014): Population dynamics of Notopterus notopterus (Pallas, 1769) from the Kaptai reservoir of Bangladesh. SAARC Journal of Agriculture 12(2): 112-122.

[49] Neira, S., Arancibia, H., Cubillos, L. (2004): Comparative analysis of trophic structure of commercial fishery species off Central Chile in 1992 and 1998. - Ecological Modelling 172(2-4): 233-248.

[50] Niesen, S. N., Ulanowicz, R. E. (2000): On the consistency between thermodynamical and network approaches to ecosystems. - Ecological Modelling 132: 23-31.

[51] Odum, E. P. (1969): The strategy of ecosystem development. - Science 104: 262-270.

[52] Odum, E. P. (1971): Fundamentals of Ecology. - W. B. Saunders Co., Philadelphia.

[53] Palaniswamy, R., Manoharan, S., Geethalakshmi, V. (2011): Assessment of population parameters of Indian major carps and common carp in a culture-based reservoir. Indian Journal of Fisheries 58(2): 41-44.

[54] Palomares, M. L. D., Pauly, D. (1998): Predicting food consumption of fish populations as functions of mortality, food type, morphometrics, temperature and salinity. - Marne Freshwater Research 49(5): 447-453. 
[55] Panikkar, P., Khan, M. F. (2008): Comparative mass-balanced trophic models to assess the impact of environmental management measures in a tropical reservoir ecosystem. Ecological Modelling 212(3-4): 280-291.

[56] Panikkar, P., Khan, M. F., Desai, V. R., Shrivastava, N. P., Sharma, A. P. (2015): Characterizing trophic interactions of a catfish dominated tropical reservoir ecosystem to assess the effects of management practices. - Environmental Biology of Fishes 98(1): 237-47.

[57] Pauly, D. (1984): Fish Population Dynamics in Tropical Waters: A Manual for Use with Programmable Calculators. ICLARM Studies and Reviews 8. - International Center for Living Aquatic Resources Management, Manila.

[58] Pauly, D., Palomares, M. L., Froese, R. (1993): Some prose on a database of indigenous knowledge on fish. - Indigenous Knowledge and Development Monitor 1(1): 26-7.

[59] Pauly, D., Christensen, V., Walters, C. (2000): Ecopath, Ecosim, and Ecospace as tools for evaluating ecosystem impact of fisheries. - ICES Journal of Marine Science 57(3): 697-706.

[60] Polovina, J. J. (1984): Models of coral reef ecosystems. I: the ECOPATH model and its application to French Frigate Shoal. - Coral Reefs 3: 1-11.

[61] Reyes, M. D. (1993): Fishpen Culture and Its Impact on the Ecosystem of Laguna de Bay, Philippines. - In: Christensen, V., Pauly, D. (eds.) Trophic Models of Aquatic Ecosystems. ICLARM Conference Proceedings 26, Manila, pp 74-84.

[62] Roy, D., Masud, A. A., Bhouiyan, N. A., Naser, M. N. (2013): Food and Feeding habits of Koi Anabas testudineus (Bloch) and indigenous catfish Rita rita (Hamilton). International Journal of Biological Research 15(1): 1-6.

[63] Sakhare, V. B., Jetithor, S. G. (2016): Food and feeding behaviour of Mozambique tilapia (Oreochromis mossambicus Peters) from Borna Reservoir of Maharashtra. Indian Journal of Fisheries 4: 431-434.

[64] Sarkar, U. K., Deepak, P. K. (2009): The diet of clown knife fish Chitala chitala (Hamilton-Buchanan) an endangered notopterid from different wild population (India). - Electronic Journal of Ichthyology 1: 11-20.

[65] Srivastava, S. M., Singh, S. P., Pandey, A. K. (2012): Food and feeding habits of threatened Notopterus notopterus in Gomti river, Lucknow (India). - Journal of Experimental Zoology, India 15(2): 395-402.

[66] Thella, R., Dahanukar, N., Eldho, P., Ali, A., Raghavan, R. (2018): Population dynamics of Wallago attu (Bloch and Schneider 1801) (Osteichthyes, Siluridae) in three small rivers of southern India. - Asian Fisheries Science 31: 172-178.

[67] Tomaczack, M. T., Jarv, L., Martin, G., Minde, A., Muller-Karulis, B., Pollumae, A., Razinkovas, A., Strake, S. (2005): Trophic networks and Carbon flows in South Eastern Baltic coastal ecosystems. - ICES CM 2005/M: 01.

[68] Traore, A., Ouattara, A., Doumbia, L., Tah, L., Moreau, J., Gourène, G. (2008): Trophic structure and interactions in Lake Ayamé (Côte d'Ivoire). - Knowledge and Management of Aquatic Ecosystem 388: 02. https://doi.org/10.1051/kmae:2008002.

[69] Travers, M., Watermeyer, K., Shannon, L. J., Shin, Y. J. (2010): Change in food web structure under scenarios of overfishing in the Southern Benguela: comparison of the Ecosim and OSMOSE modelling approaches. - Journal of Marine Systems 79: 101111.

[70] Ulanowicz, R. E. (1986): Growth and Development: Ecosystem Phenomenology. Springer-Verlag, New York.

[71] Ulanowicz, R. E. (1997): Ecology, the Ascendent Perspective. - Columbia University Press, New York.

[72] Ulanowicz, R. E., Norden, J. S. (1990): Symmetrical overhead in flow networks. International Journal of Systematic Science 21: 429-437.

[73] Ulanowicz, R. E., Puccia, C. J. (1990): Mixed trophic impacts in ecosystems. Coenoses 5: 7-16. 
[74] Villanueva, M. C., Ouedraogo, M., Moreau, J. (2006): Trophic relationships in the recently impounded Bagré reservoir in Burkina Faso. - Ecological Modelling 191(2): 243-259.

[75] Weliange, W. S., Amarasinghe, U. S. (2007): Relationship between body shape and food habits of fish from three reservoirs of Sri Lanka. - Asian Fisheries Science 20: 257-270.

[76] Wolff, M. (1994): A trophic model for Tongoy Bay - a system exposed to suspended scallop culture (Northern Chile). - Journal of Experimental Marine Biology and Ecology 182: 149-168.

\section{APPENDIX}

Table A1. Population parameters of the representative species of different functional groups used for pre-fishing ban (2001) and post-fishing ban period (2016) in Kaptai reservoir system

\begin{tabular}{|c|c|c|c|c|c|c|c|}
\hline Group/species & $\mathbf{L}_{\infty}$ & $\mathbf{K}\left(\mathbf{y r}^{-1}\right)$ & $\mathbf{M}\left(\mathbf{y r}^{-1}\right)$ & $\mathbf{F}\left(\mathbf{y r}^{-1}\right)$ & $\mathrm{Z}\left(\mathrm{yr}^{-1}\right)$ & $\mathbf{E}$ & Reference \\
\hline Carps & & & & & & & \\
\hline Labeo rohita & 93.28 & 0.920 & 1.220 & 1.310 & 2.53 & 0.500 & Ahmed et al., 2005 \\
\hline Catla catla & 94.30 & 0.959 & 0.629 & 2.600 & 3.23 & 0.805 & Palaniswamy et al., 2011 \\
\hline Cirrhinus cirrhosus & 71.00 & 0.845 & 0.627 & 1.470 & 2.1 & 0.701 & Palaniswamy et al., 2011 \\
\hline Labeo calbasu & 69.00 & 1.100 & 1.480 & 4.230 & 5.71 & 0.740 & Haroon et al.,2001 \\
\hline Labeo bata & 32.10 & 1.500 & 2.285 & 1.400 & 2.80 & 0.500 & Azadi et al., 1996 \\
\hline Labeo gonius & 53.00 & 0.890 & 1.390 & 1.390 & 2.78 & 0.500 & Haroon et al., 2001 \\
\hline Cyprinus carpio & 58.66 & 0.958 & 0.708 & 1.412 & 2.12 & 0.663 & Palaniswamy et al., 2011 \\
\hline $\begin{array}{c}\text { Catfishes } \\
\text { Sheatfishes }\end{array}$ & 53.00 & 0.280 & 0.450 & 0.450 & 0.90 & 0.500 & Villanueva et al., 2006 \\
\hline Wallago attu & 99.75 & 1.300 & 1.470 & 1.900 & 3.37 & 0.560 & Thella et al., 2018 \\
\hline $\begin{array}{c}\text { Ompok pabda } \\
\text { Tilapia }\end{array}$ & 21.00 & 1.000 & 1.920 & 0.290 & 2.22 & 0.130 & Gupta et al., 2015 \\
\hline Oreochromis niloticus & 55.59 & 0.390 & 0.800 & 0.590 & 1.39 & 0.420 & Ahmed et al., 2003 \\
\hline $\begin{array}{c}\text { Anabas testudineus } \\
\text { Knife fishes }\end{array}$ & 17.10 & 1.400 & 2.520 & 1.895 & 3.79 & 0.500 & Mustafa and Graaf, 2008 \\
\hline $\begin{array}{c}\text { Notopteurs notopterus } \\
\text { Snakehead }\end{array}$ & 34.91 & 0.380 & 0.910 & 0.280 & 1.19 & 0.240 & Mustafa et al.,2014 \\
\hline $\begin{array}{c}\text { Channa punctatus } \\
\text { Minnows }\end{array}$ & 24.00 & 0.900 & 2.160 & 1.565 & 3.13 & 0.500 & Mustafa and Graaf, 2008 \\
\hline Puntius sarana & 26.00 & 0.400 & 0.930 & 1.640 & 2.57 & 0.640 & FishBase \\
\hline $\begin{array}{c}\text { Amblypharyngodon mola } \\
\text { Clupeids }\end{array}$ & 10.46 & 0.950 & 1.220 & 2.040 & 3.26 & 0.630 & Azadi and Mamun, 2009 \\
\hline Corica soborna & 5.700 & 2.620 & 5.110 & 3.400 & 8.51 & 0.400 & FishBase \\
\hline Gudusia chapra & 19.40 & 1.230 & 2.450 & 4.180 & 6.63 & 0.630 & Kumari et al., 2018 \\
\hline
\end{tabular}


Table A2. Input diet matrix for different functional groups for pre-fishing ban (2001) and postfishing ban period (2016) in Kaptai reservoir

\begin{tabular}{|c|c|c|c|c|c|c|c|c|c|c|c|c|c|}
\hline Group no. & Prey/predator & 1 & 2 & 3 & 4 & 5 & 6 & 7 & 8 & 9 & 10 & 11 & 12 \\
\hline 1 & Carps & - & 0.065 & - & - & - & - & $\left(\begin{array}{c}- \\
(\mathbf{0 . 1 5 0})\end{array}\right.$ & - & - & - & - & - \\
\hline 2 & Catfishes & - & 0.023 & 0.150 & - & - & - & 0.015 & - & - & - & - & - \\
\hline 3 & Sheatfishes & - & 0.009 & - & - & - & - & 0.07 & - & - & - & - & - \\
\hline 4 & Tilapia & - & 0.025 & - & - & - & - & - & - & - & - & - & - \\
\hline 5 & Anabas testudineus & - & 0.005 & - & - & - & - & - & - & - & - & - & - \\
\hline 6 & Knife fishes & - & 0.003 & - & - & - & - & - & - & - & - & - & - \\
\hline 7 & Snakehead & - & 0.05 & - & - & - & - & - & - & - & - & - & - \\
\hline 8 & Minnows & - & 0.17 & 0.340 & - & 0.110 & 0.100 & 0.228 & - & - & - & - & - \\
\hline 9 & Clupeids & - & 0.25 & 0.100 & - & 0.200 & 0.200 & 0.310 & - & - & - & - & - \\
\hline 10 & Prawns & - & 0.08 & 0.200 & - & 0.050 & 0.350 & $\begin{array}{l}0.180 \\
(\mathbf{0 . 0 5})\end{array}$ & - & 0.050 & 0.05 & - & - \\
\hline 11 & Insects/larvae & 0.075 & 0.15 & - & 0.050 & 0.160 & 0.180 & $\begin{array}{c}0.080 \\
(\mathbf{0 . 0 0 4})\end{array}$ & - & 0.050 & 0.2 & - & - \\
\hline 12 & Zooplankton & 0.055 & 0.07 & - & 0.246 & 0.260 & 0.090 & 0.060 & 0.130 & 0.425 & 0.2 & 0.125 & 0.05 \\
\hline 13 & Phytoplankton & 0.520 & 0.05 & 0.080 & 0.700 & 0.110 & 0.050 & 0.025 & 0.850 & 0.375 & 0.1 & 0.305 & 0.8 \\
\hline 14 & Detritus & 0.350 & 0.05 & 0.130 & 0.004 & 0.110 & 0.030 & $\begin{array}{c}0.032 \\
(\mathbf{0 . 0 8 8})\end{array}$ & 0.020 & 0.100 & 0.45 & 0.570 & 0.15 \\
\hline
\end{tabular}

*The input value within bracket (bold) were used for modelling of pre-fishing ban period (2001) 